БКК 67.7

\title{
АКТУАЛЬНЫЕ ПРОБЛЕМЫ ЗАКРЕПЛЕНИЯ ЭКОНОМИЧЕСКИХ ОСНОВ КОНСТИТУЦИОННОГО СТРОЯ РОССИЙСКОЙ ФЕДЕРАЦИИ В УСЛОВИЯХ ЛИБЕРАЛЬНОЙ ДЕМОКРАТИИ
}

\author{
(c) 2020 Ревина Светлана Николаевна \\ доктор юридических наук, профессор \\ Самарский государственный экономический университет, Россия, Самара \\ E-mail: 29.revina@mail.ru \\ (c) 2020 Павлова Александра Сергеевна \\ магистрант \\ Самарский государственный экономический университет, Россия, Самара \\ E-mail: pavlin0902@mail.ru
}

В статье описываются актуальные проблемы экономических основ конституционного строя, раскрываются их наиболее значимые принципы и основы, говорится о их правовом закреплении, обсуждается вопрос планирования экономического развития страны. На любом этапе развития государства этот вопрос не теряет своей актуальности, поскольку экономическое развитие любого государства является неотъемлемым элементом устойчивой рыночной экономики без намека на всякого рода монополии, способствующей здоровому развитию демократии и поддержания общественных отношений. Все вышеперечисленные вопросы и проблемы находят своё отражение в современной правовой науке, что способствует регулированию общественных отношений на территории РФ. В статье уделяется внимание экономическим основам конституционного строя, именно такие исходные положения закреплены в основном законе страны - Конституции РФ, стоит отметить, что эти основы несут в себе принципы управления экономикой. Конкретно, к принципам экономических основ относят: единство экономического пространства, свободное перемещение финансовых средств, товаров, услуг, поддержка здоровой конкуренции, свобода. Никак не обойтись и без штрафных санкций, так в статье будут указаны органы и санкции, применяемые к нарушителям установленных законом правил. Обратим внимание на то, что в данной статье мы обращаемся к одному известному правоведу, а именно при написании статьи, была уделено внимание трудам В.А.Григорьевой, так как именно она, одна из немногих говорила о взаимосвязи государственного планирования и института конституционного права.

Ключевые слова: экономические основы, конституционный строй, демократия, либеральная демократия, рыночная экономика, принципы, граждане, единство экономического пространства.

Экономические основы это одна из важнейших составных частей конституционного строя Российской Федерации (далее РФ), на данный момент экономические основы играют важную роль в нашем строящемся демократическом обществе. Стоит отметить, что при принятии Конституции РФ 1993 г. отмечалось переплетение политических и экономических основ вместе с либеральным характером нововведений.

Изучая Конституцию РФ можно обратить внимание на то, что принципы рыночной экономики играют главенствующую роль, не смотря на то, что никакого понятия «рыночной экономики» в Конституции РФ нет, в ст.8 закреплены лишь основы рыночной экономики: «В Российской Федерации гарантируются единство эко- номического пространства, свободное перемещение товаров, услуг и финансовых средств, поддержка конкуренции, свобода экономической деятельности».

Говоря о тесном переплетении экономических и политических основ с либеральноэкономическим характером, стоит отметить и то, что же такое экономический либерализм, во-первых, либерализм - это идейное течение философского и общественно-политического характера, провозглашающее незыблемость индивидуальных свобод и прав человеческого общества, его индивидов, выступающих за снижение степени влияния государства на общественную жизнь. Либеральная демократия РФ находит свое отражение в принципе, суть 
которого заключатся в осуществлении руководства и управления экономикой государства, то есть в данном случае все обращено на создание и обеспечение здоровой конкуренции и предупреждение возникновения признаков монополии. Об этом упоминается и в Основном законе нашего государства, ч.2 ст.34 Конституции РФ гласит, что «не допускается экономическая деятельность, направленная на монополизацию и недобросовестную конкуренцию». Бесспорно, без конкуренции нельзя представить рыночную экономику, так как именно этот фактор является механизмом, способствующим работе ценам на рынке. В дальнейшем это действие зарождает цепочку спроса и предложения, как на рынке товаров, так и на рынке услуг, поэтому государству важно контролировать и предотвращать монополию, опираясь при этом на Конституцию [1].

Проявление экономического либерализма можно отследить в таком конституционном рыночном принципе руководства и управления экономикой, как единство экономического пространства в РФ, которое тоже находит свое отражение в Конституции, а также закрепляет гарантии при перемещении товаров, услуг и финансовых средств на территории государства.

Нельзя оставить без внимания тот факт, что в конституционном законодательстве РФ по сей день не нашел своего отражения и правового закрепления принцип государственного планирования экономического развития страны. В 2020 г., а именно 1 июля 2020 года пройдет голосование, на повестке стоит вопрос Конституции РФ с поправками, в этом случае гражданам нужно будет сделать выбор, проголосовать за поправки или против. Обратим внимание на то, что ни в настоящей Конституции РФ, ни в Конституции с поправками нет ни слова о экономическом планировании экономического развития страны, на наш взгляд, отсутствие такого в Основном законе страны может значительно замедлить экономическое развитие в будущем, отодвинуть наше государство от государств в развитой рыночной экономикой, а это США, Германия, Япония, Италия, Великобритания и Франция.

Главным отличием государства с планированием экономического развития и без такового заключается в том, что в условиях рыночной экономики предполагается использование лишь экономических, то есть рыночных механизмов, все это делает производство намного выгоднее, и менее убыточнее, в отдельных регионах страны.
Если сравнивать отечественную и западную экономическую науку, то стоит отметить, что развитые страны на протяжении долгих лет практикуют стратегическое планирование и прогнозирование. Так стратегическое планирование - это процесс определения целей и значений экономических показателей по наиболее важным направлениям социально-экономического развития страны, прогнозирование - это разработка аргументированных представлений о рисках социально-экономического развития, даже исходя из понятий, можно обратить внимание на то, как взаимосвязано между собой стратегическое планирование и прогнозирование. Неотъемлемой частью рыночного хозяйства 21 века стало планирование, но как мы уже отметили ранее, правового закрепления в Основном законе страны это не нашло, но несмотря на это широко применяется. Опыт зарубежных стран оказывает нам то, что путем государственного влияния допустимы поправки в экономической сфере, следовательно, возможно влияние на рыночные отношения, а все это в дальнейшем способствует укреплению социально-экономического развитие общества [2].

Закрепление планирования экономического развития страны на государственном уровне очень важное условие, поскольку это является неотъемлемым элементом стабильной рыночной экономики, так как планирование основано на анализе как внешних, так и внутренних факторов, оказывающих влияние на экономику. Благодаря планированию возрастает координация действий, вырабатываются возможности, необходимые для подготовки ресурсной базы, под этим можно понимать, как сырьевые, так и трудовые ресурсы, следовательно, все это имеет отголоски в теории правовой науки РФ, в практике правового регулирования общественных отношений, возникающих в данном отрасли на данном этапе.

Обращаясь к высказывания правоведов, можно отметить В.А.Григорьеву, именно она, одна из немногих, причисляет государственное планирование к такому институту, как конституционное право, по ее мнению, данный институт отражает цели отдельных областей и отраслей национальной экономики, указывая на механизм их достижения. Автор говорит о том, что наиболее важные законы в России принимаются совершенно неупорядоченно, без нормативноустановленных порядка, классификаций и требований к содержанию [3]. 
Как мы уже говорили ранее, под экономической основой конституционного строя понимают упорядоченные и закрепленные Конституцией РФ формы собственности и принципы управления экономикой. К принципам экономических основ относятся: единство экономического пространства, свободное перемещение финансовых средств, товаров, услуг, здоровая конкуренция, свобода экономической деятельности, многообразие и разная защита форм собственности [4].

На наш взгляд одним из актуальных является принцип поддержки конкуренции, так как при ее отсутствии о какой рыночной экономике может вообще идти речь. Государство создает все условия для поддержания здоровой конкуренции, ограничивает монополистическую деятельность, при этом стимулируя производителей к снижению издержек на производстве и все это способствует дальнейшему научнотехническому прогрессу. Не стоит забывать, что конкуренция - это борьба между субъектами за наиболее выгодное использование землей, капиталом, трудом. Именно конкуренция позволяет разнообразить товары и услуги на рынке, улучшить их качество, а также поднять жизненный уровень населения [5]. Как мы уже сказали ранее, государство способствует созданию здоровой конкуренции в стране, а все это происходит благодаря созданию в соответствии с указом Президента России № 314 от 9 марта 2004 года Федеральной антимонопольной службе, где целью являлась конкурентная среда хозяйствующих субъектов, равный доступ к товарам, услугам и развитие конкуренции, а также эффективная реализация государственной политики конкретно в области контроля иностранных инвестиций. Такой орган может выносить предписания действиям, имеющим монополистический характер, а также назначать наказания в виде штрафа. Обратим внимание и на то, что в такой ситуации штрафом все не заканчивается, так как при таких действиях штраф оплачивается государству, а все убытки, причиненные пострадавшей стороне, взыскиваются через суд. Стоит указать, и то, что он, в отличие от принципа «планирования» закреплен, а как мы уже сказали, его несоблюдение влечет за собой наказание, в «планировании» все это отсутствует [6].

Выделим еще один наиболее важный принцип, ключевая функция которого состоит в свободном передвижении финансовых средств, а также товаров и услуг. Принцип, раскрытый ра- нее тесно связан с принципом единства экономического пространства, этот принцип означает недопущение на территории нашего государства установки таможенных границ, пошлин, сборов, не смотря на это, на территории РФ могут вводиться ограничения на передвижение определенных товаров, но все это делается исходя из ряда определенных, установленных федеральных законов, а происходит это в случаях, необходимых в обеспечении охраны и зашиты прав населения и граждан [7].

Следующим, наиболее актуальным принципом на наш взгляд является принцип свободной экономической деятельности. Это принцип характеризуется всесторонней правовой защитой интересов, как производителей, так и потребителей, то есть смело можно сказать о том, что в этом случае защищены все. Вопрос, касающийся регулирования деятельности такового, государство на половину берет на себя, так как общие условия заключения договора аренды, а также купли-продажи, поставок и стандарты качества определяет именно государство. При этом немаловажную роль играет развитие банковской системы, системы пенсионного и инвестиционного фонда, бирж, страховых компаний. Под свободой экономической деятельности понимается регулирование деятельности предпринимателей в этом случае, государственный органы не должны вмешиваться в деятельность предпринимателей, так как такая деятельность поддерживается и регулируется через гражданское и финансовое законодательство.

Все вышеперечисленные принципы имеют закрепление в соответствующих федеральных законах, а их несоблюдение, как мы уже говорили, в некоторых случаях влечет за собой наказание. Для более эффективного развития экономики Российской Федерации, считаем, стоит закрепить планирование экономического развития страны, так как стратегическое планирование - залог успешного экономического развития страны, а экономика нашего государства постоянно претерпевает изменения и развивается. В нашем государстве учитываются интересы, как граждан, так и юридических лиц, об этом упоминалось ранее, и из всего сказанного следует, что Российская Федерация является либеральным демократическим государством с устойчиво развивающейся рыночной экономикой, но с отсутствием закрепления на государственном уровне стратегического планирования. 


\section{Библиографический список}

1. Конституция Российской Федерации «Конституция Российской Федерации» (принята всенародным голосованием 12.12.1993 с изменениями, одобренными в ходе общероссийского голосования 01.07.2020) [Электронный ресурс]// СПС КонслультантПлюс.

2. Быков А. Ю. Инвестиционный климат экономической стабильности // Юрист 2020. № 1. С.59-66.

3. Григорьева В.А. Стратегическое экономическое планирование государства: конституционно-правовой аспект // Актуальные проблемы российского права. 2013. № 8. С.959. (958-966)

4. Прудентов Р.В. Метод правового регулирования: вопросы теории и конституционного права: монография / Р. В.Прудентов.- Москва.: Статут, 2019. С.152 (192)

5. Авакьян С.A. Конституционно-правовые основы антикоррупционных реформ в России и за рубежом. Учебно-методический комплекс (учебное пособие) / Отв. ред.д.ю.н., проф.С.А.Авакьян.-М.: Юстицинформ,2016. (568)

6. Кожевников И.Н. Сравнительно-правовой анализ понятия добросовестной конкуренции по законодательству России, Франции и Германии // Юрист 2020. № 2. С.25-33.

7. Агапова И.И. История экономики: учеб.пособие.-М., 2012. 